\title{
INTERVIEW WITH ASSAR LINDBECK
}

\author{
THORVALDUR GYLFASON
}

CESIFO WORKING PAPER NO. 1408

CATEgORY 6: MONETARY POLICY AND INTERNATIONAL FinanCE

FEBRUARY 2005

An electronic version of the paper may be downloaded

- from the SSRN website:

www.SSRN.com

- from the CESifo website:

www.CESifo.de 


\title{
INTERVIEW WITH ASSAR LINDBECK
}

\begin{abstract}
Macroeconomic Dynamics commissioned this interview with Assar Lindbeck for a series of such conversations with economists, starting with Duncan Foley's interview with Wassily Leontief in 1998. Other interviews in the series include Ben McCallum's interview with Robert Lucas (1999), Olivier Blanchard's interview with Janos Kornai (1999), Daniel Trefler's interview with Elhanan Helpman (1999), William Barnett and Robert Solow's interview with Franco Modigliani (2000), John Taylor's interview with Milton Friedman (2001), James Poterba's interview with Martin Feldstein (2003), Brian Snowdon's interview with Axel Leijonhufvud (2003), William Barnett's interview with Paul Samuelson (2003), and John Campbell's interview with Robert Shiller (2004). Forthcoming interviews include Olivier Blanchard's interview with Stanley Fischer (2005), Omar Licandro and Pierre Dehez's interview with Jacques Drèze (2005), and George Evans and Seppo Honkapohja's interview with Tom Sargent (2005).
\end{abstract}

JEL Code: A10.

Thorvaldur Gylfason

University of Iceland

Faculty of Economics and Business Administration

101 Reykjavik

Iceland

gylfason@hi.is 
21 January 2005.

MD Interview

\section{An Interview with Assar Lindbeck}

Interview by Thorvaldur Gylfason

University of Iceland and CEPR

Keywords: Endogenous politicians, incentive problems, social norms, welfare state, unemployment.

Sweden has a long and distinguished tradition in economics, beginning with Knut Wicksell and continuing with Gustav Cassel, Eli Heckscher, Erik Lindahl, Gunnar Myrdal, Bertil Ohlin, and Erik Lundberg, all of whom are now gone. Yet, for several of these men, economics was not enough: Wicksell spoke out on moral issues and did time in jail, Myrdal was for many years a high official at the United Nations and, briefly, a cabinet minister, as was Ohlin who at home made his mark primarily as leader of the opposition in a country governed mostly by Social Democrats, serving in parliament for 32 years. For Assar Lindbeck, however, economics has been broad enough: he has devoted a long and distinguished career over half a century to economics, and to economics alone, with unfailing enthusiasm and energy. Not that he was not wanted elsewhere: over the years, he has declined challenging job offers from an international organization and a Swedish daily newspaper, to name but two examples, as well as from universities outside Sweden. Assar has managed to harness his varied and wide-ranging talents within the many mansions of economics. He is one of the most versatile economists of his generation. Indeed, he is one of those few who, for clarity, need to divide their bibliography into categories by subject: Macroeconomics and monetary economics, Public economics, Labor economics, International economics, Economic systems and economic structures, Methodology and history of economic thought, and Swedish economy. His work on these different subjects has ranged from pure theory to applied policy-oriented and empirical studies. In addition to the numerous scientific publications listed at the end of this interview, his bibliography includes nearly 200 articles for magazines and newspapers. His ivory tower has always been equipped with a high-speed lift. But, as he points out in the 
conversation to follow, all his research work as well as his journalism is driven by an overarching interest in bettering economic policy and organization - in other words, boosting economic and social efficiency for the purpose of lifting ordinary people's standard of life. This has been, and remains, a guiding principle - a Leitmotiv if you prefer - from which he has never swerved. Assar Lindbeck is a towering figure in Swedish economics, and in Swedish national life.

Gylfason: Let's not begin at the beginning. According to local legend, Tage Erlander, Sweden's Prime Minister from 1946 to 1969, asked you in the early 1950s to become his personal assistant. What happened?

Lindbeck: In May 1953, I attended a political conference for social-democratic university students, where Tage Erlander talked about constitutional issues, and I jumped (as always!) into the discussion. In view of my rather critical comments to his speech, I was surprised when afterwards he came up to my lunch-table and asked if I would like to be his political secretary (assistant). I answered that it would have been interesting, but that I was going to start a twelve-month stint of (compulsory) military service the next day. But I have a friend that would be suitable for the job, I said, Olof Palme, who at the time was the chairman of Swedish Students' Association. I suggested that Palme would be the right man. I remember Erlander's spontaneous reaction: "Good grief, is he a Social Democrat?" Within a few weeks, Palme was hired part-time - to work simultaneously with his permanent position at the Staff of Defense (Försvarsstaben). This was the beginning of his political career - and the end of mine.

Gylfason: What was it like to study economics at Uppsala in the early 1950s?

Lindbeck: A graduate student in Sweden at that time was first supposed to devote a number of years to a "licentiat-exam." This included oral examinations on the basis of a long reading list, which was composed in cooperation with the professor(s) at the Department. Second, the student was supposed to write a licentiate dissertation. A normal time for a licentiate degree was, I believe, three to four years. To get a doctor's degree you had subsequently to write a doctoral dissertation, which had to be a printed book. This usually took two to four more years, although the time tended to infinity in some cases. In some natural sciences, the time was, however, shorter. There were no graduate $(\mathrm{PhD})$ courses at Swedish Universities at that time. The only type of 
organized education at the $\mathrm{PhD}$ level was a requirement to attend a "Higher seminar" once every week.

I started my graduate studies in Uppsala in 1952. Although the faculty was very small, the seminar was usually attended by some excellent scholars: Erik Lindahl, Tord Palander, Bent Hansen, and Ragnar Bentzel. In addition to intellectual stimulation, I learnt that the speed of an intellect is something very different from its depth: Erik Lindahl was extremely slow at seminars, and he seldom won an oral discussion. But when he sat down with paper and pencil (as well as scissors and glue!), he made contributions far deeper than most fast thinkers. I pursued graduate studies in Uppsala only for about a year, using most of my time to learn mathematics better by the help of R.G.D.Allen's book “Mathematical Analysis for Economists."

Gylfason: After finishing your master's degree in economics in Uppsala in 1952, your first paid professional job - first part-time, then full time - was in the Ministry of Finance in Stockholm. You were at the same time working on your licentiate dissertation, which dealt with aspects of fiscal policy, right?

Lindbeck: I moved over to Stockholm (late in the summer of 1953) when my military service was moved from ordinary military duties at the Signal Troops in Uppsala to statistical work for the Army Headquarter (Arméstaben) in Stockholm. After a few months at the Headquarter, however, I received a phone call from the undersecretary of the Treasury (Gunnar Lange), who asked if I would be interested in part-time work in the Treasury, simultaneously with my military service. The idea was that I would work full-time after the military service, a suggestion that I accepted. I guess that the Army Headquarter was too dependent on the Treasury to say "no" to this rather unorthodox arrangement. They even accepted that I could sit most of the time in the Treasury - also for my work for the Headquarter, which was rather trivial descriptive statistical work. (My more traditional military training consisted of the duty to train shooting at the Cavalery Regiment one hour every Friday morning.)

The same type of arrangement continued when I was shifted over from the Army Headquarter to the Defense Staff (Försvarsstaben), where I worked together with Olof Palme. Here my tasks were more challenging. One project was to analyze the total resource costs (including the opportunity costs) of military defense spending in Sweden, the United States, and the Soviet Union. Since Palme's background was in law, I had to carry the main burden in this particular project. Another project was to follow the political and military development in French Indochina. Here Palme was 
the more active (and knowledgeable) one. His great interest in Vietnam certainly went back (at least) to this period (1953-1954).

In the Treasury, I worked mainly in the economic analysis group (consisting of four persons altogether!). I also worked directly for the secretary of the Treasury (to begin with Per Edwin Sköld and subsequently Gunnar Sträng), for instance, providing input to speeches and parliamentary discussions. Even though my somewhat less than two-year stay in the Treasury delayed my academic studies, I also learned lots of things. For instance, I acquired a skeptic attitude to what politicians can achieve, and I learned how important short-term tactical issues were for them. A standard question of members of government was: how will the national economy develop up until next election? This experience was the background for my work in the early 1970s on the issue of "endogenous politicians." In particular, I noted that the time of election created a special discontinuity of policies. My understanding of stabilization policy behavior was that responsible politicians during approximately a year immediately before an election wanted to fight what the general public believed to be the main macroeconomic problem during that particular period, regardless of whether this was inflation or unemployment, while the consequences emerging immediately after the election were of less importance. Of course, this does not mean that politicians always would like to "blow up" the economy immediately before the election. The opposite would be more likely if high inflation at that time was regarded as the main problem.

Gylfason: Did you at any time consider devoting your professional life to civil service, at home or abroad, rather than to an academic career?

Lindbeck: Yes, I did consider this option a number of times. But during my stay in the Treasury I basically learned more about my own preferences. I became convinced that my right place was in academia, rather than in politics or public administration. One reason, of course, is that academic work is so intellectually rewarding. But another equally important reason is that in academia I can do, and say, exactly what I want, which is impossible in large organizations.

Returning to academic studies in 1954, now at Stockholm University (at that time called Stockholms Högskola), I was back struggling with the literature on my reading list, which was growing rapidly with Erik Lundberg as my mentor. I started this time with Allen's second book "Mathematical Economics." But what really turned me on was the manuscript of Bent Hansen's book "The Theory of Fiscal Policy," which was discussed at Erik Lundberg's Higher seminar, often with me as the appointed 
discussant (since there were hardly any other graduate students in the department at that time). I discovered how useful simple mathematical models can be in analyzing important economic policy issues. Moreover, when I followed up Bent Hansen's literature references, the most important track led to Paul Samuelson's "Foundations of Economic Analysis", which became my bread and butter for a number of months (although the bread was often hard chewing). There is no exaggeration that these two books were the first stepping-stones on my route to becoming a professional economist.

But after less than a year of lonely studies, the Treasury Department intervened in my life again (in December 1954). The new Undersecretary (Erik Westerlind) asked for my comments on his analysis of the effects of the Government budget, to be presented to parliament in January 1955. I answered that the exposition was not the right way to analyze the macroeconomic effects of fiscal policy; my objection was largely based on what I had just learnt from Bent Hansen's work. The under-secretary answered: "Do it better yourself," and I was assigned the task of preparing an empirical study of the macroeconomic effects of the state budgets in recent years. I accepted the kind offer not because I was keen on making a career in the Treasury, but because I saw an excellent way of financing my work for the licentiate dissertation. I got an office again in the Treasury, where the job took about a year (from the early spring of 1955 to the early spring of 1956). The study was printed as an official Government report (SOU 1956:48), with a preface by the finance minister.

Gylfason: What, then, was the point in the study?

Lindbeck: Rather than using the budget surplus as an indicator of the macroeconomic effects of the budget, which was the traditional approach, I made separate analyses of the impact on aggregate demand of discretionary fiscal policy measures and of automatic budget changes (the automatic stabilizer). The way I quantified the impact effect of discretionary policy measures were somewhat similar to what in the United State was later called the "full employment surplus." In both cases, the discretionary effect was measured at a given level of capacity utilization, although in my study at the existing level rather than, as in calculations of the full employment surplus, at full capacity utilization. My study was, however, more disaggregated than (later) analyses in terms of the full employment surplus, since I looked separately at all budget measures during a specific year, subsequently adding them to an aggregate measure. In terms of a simple Keynesian 45-degree diagram, we 
may say that I tried to estimate the multiplicand of the demand effects of all policy measures during a year. (Later on, I found out that E. Cary Brown simultaneously and independently had made a somewhat similar study of the effects of discretionary fiscal policy in the United States in the 1930s; he did not, however, make a separate analysis of the effect of the automatic fiscal stabilizer.)

The dissertation was never translated to English. But the same analytical framework was later used by an expert group, appointed by the OECD, studying the macroeconomic effects of fiscal policies in all OECD countries. (Walter Heller was the chairman of this group, I was one of the members, and Bent Hansen was the secretary). I summarized the methods and result of the study in Kyklos 1970.

Gylfason: What attracted a young man in the far north of Sweden - someone with enough artistic talent to have performed his own sonata for clarinet and piano at a public concert at the age of eighteen - to economics? I know your father was active in the Social Democratic movement at the local level, so I suppose one could perhaps say that you were born into the movement, right? Looking back, how would you describe these early influences on your decision to become an economist and on your work as an economist?

Lindbeck: We often discussed politics at my home when I was a child, not least at the dinner table. Since my father was Chairman of the Governing Municipal Body ("Stadsfullmäktiges ordförande") in my hometown (Luleå in the far north of Sweden) I often met local and occasionally also national politicians as a child in my home. This probably stimulated my political interest. Perhaps even more important: my father was in charge of the welfare administration in northern Sweden, and I sometimes followed him on his travels (in the late 1930s and during the 1940s) to poor villages, where people could hardly survive without government support. I think this experience is an important source of my interest in social issues, and my subsequent extensive writings about the welfare state. In retrospect, I am also struck by how strong the norms were at that time against living on handouts from the government. My father often told me how difficult it often was to convince poor people that they needed support from the government. Today, by contrast, different groups of citizens compete for benefits, and individuals are quite eager to get as generous benefits as possible, although some stigmatization still exists also in Sweden in the case of highly discretionary benefits, such as social assistance ("welfare" in US terminology). 
So, against this background of mine, it is perhaps easy to understand why I chose to study social sciences rather than my other main field of interest, music. I am not even sure that I would have been admitted as a student to the Academy of Music in Stockholm. Moreover, when I listen to brilliant musicians on radio or television today, I realize how limited my own talent really was in that field.

Gylfason: You have managed to do many different things in your career: your main commitment is to research, yes, but your service to your country - and not only to your country, but outside Sweden as well - as an economic advisor and as an educator, debater, and journalist is also widely admired and appreciated. How do you see the role of an economist in modern society?

Lindbeck: The theory of comparative advantage should apply also within our own profession. We have to accept different roles for different economists - from the most abstract mathematical economists to highly applied ones - some in the latter group using highly technical methods of analysis, others making more essayistic expositions. Some economists, of course, try to make contributions to both theory and applications, and they may also shift between highly technical methods and verbal discussions, but that is hard work.

Gylfason: I wonder if absolute advantage doesn't have something to do with it as well.

Lindbeck: You mean that some leading academic economists occasionally may also make outstanding contributions to highly applied policy issues? There are, of course, such examples. Wicksell, Cassel, and Heckscher all made important contributions not only to academic research but also to the economic policy discussion in Sweden before World War II. Something similar may be said about leading economists of the "Stockholm School" in the 1930s and during the first postWorld War II decades: Erik Lindahl, Gunnar Myrdal, Bertil Ohlin, and Erik Lundberg. You can, of course, find similar examples in other countries. We should perhaps be happy that these people occasionally violated the principle of comparative advantage by their interventions in the economic policy discussion.

Gylfason: Before moving to Stockholm to teach and to complete your doctoral dissertation, you spent nearly two years in the United States - at the University of Michigan, the Federal Reserve Board in Washington, D.C., and at Yale. What were your first impressions of America? Have they changed with the passage of time? 
Lindbeck: I first arrived to the United States as a Rockefeller student in April 1957, where I had the privilege of having James Tobin and Richard Musgrave as my main mentors at Yale and Michigan, respectively. This was a time when the struggle against school segregation had just been accentuated, which was interesting to follow in the media. This development has stuck in my mind as a reflection both of the serious social and ethnic problems in the United States, and of the hard and committed work by many citizens to do something about it.

It is also difficult to forget the shock among students and faculty at Yale when the Sputnik was launched by the Soviet Union in 1957. Everybody came out of their offices, and they stood on the ground discussing this unexpected challenge to US technological leadership.

During my stay in the US, I was also struck by the high-quality service in stores, restaurants, etc. Indeed, at that time the United State service sector was a model for Europe - which I feel is less the case today.

Gylfason: Even so, Aleksey Kosygin, the Soviet premier (1964-1980), was deeply impressed by the same thing, twenty years later.

Lindbeck: When it comes to the academic community, I was, of course, impressed by the high quality of the $\mathrm{PhD}$ courses that I attended - often given by teachers with a strong European accent, both at Yale and the University of Michigan. However, I was surprised by the pronounced partisan positions that many American academics took on political issues - much like members of fan clubs of football teams in Europe. I wonder why. On my latest visit to the United States, around the presidential election in 2004, this partisan engagement was even stronger.

Gylfason: Endogenous economists, perhaps?

Lindbeck: In Sweden, which is supposed to be a highly politicized country, I seldom know which party my colleagues even vote for.

Gylfason: And then you went back to Stockholm University where you completed your doctoral dissertation. Before I ask you about your thesis, let me ask you this: was it in Stockholm that you got to know Gunnar Myrdal, Bertil Ohlin, and Erik Lundberg? What role did they play in your development as an economist? - and in Sweden's national life in general.

Lindbeck: All of them have been important for Swedish society. After I took over Gunnar Myrdal's chair at Stockholm University in 1971, I had quite a lot to do with him. His most lasting influence in Sweden is his push, together with Alva Myrdal, for 
government interventions in the affairs of the family. They were instrumental for social legislation that, to a considerable extent, has "socialized the family" rather than production firms. By that I mean that public-sector institutions have taken over traditional family tasks to a considerable extent - such as child care and old-age care and also made the family highly dependent on government-provided benefits of different types in the course of the life cycle. The government also intervenes to influence the allocation of time between husbands and wives within the family (via rules about rights of family members to stay at home to take care of children). It is interesting to look at these developments against the background of Alva and Gunnar Myrdal's writing on these issues starting in the mid-1930s.

As a more personal characterization of Gunnar Myrdal, I would say that he was very fast not only in identifying new problems, but also in expressing personal views on them, although often without giving up his previous opinions on the same issues. Over time, his views therefore looked more and more like "archeological layers" of positions that he had taken during different phases of his life - each of them usually quite profound. It was, however, not always easy to know which of the layers you were confronted with when you talked to him - for instance, Myrdal the central planner or Myrdal the anarchist.

Ohlin's and Lundberg's main imprint on Swedish society, I believe, is that they helped to dampen the political enthusiasm for central planning and nationalization during the first decade after World War II. They were also important advocates of free trade. Lundberg, moreover, convinced many Swedish economists about the limits, indeed dangers, of attempts to "fine tune" macroeconomic policies. He also helped Swedish economists to appreciate the advantages of well functioning markets, although the work that clarified this point most effectively for me was Hayek's little article "The Use of Knowledge in Society," in the American Economic Review in 1945 - an article also highly appreciated by Lundberg.

Gylfason: Your doctoral dissertation dealt with monetary analysis. For you and others working in this area at the time, Don Patinkin's work that culminated in his Money, Interest and Prices (1956) was your main inspiration, I suppose, in addition to Keynes. What economists have had the greatest influence on you over the years?

Lindbeck: Patinkin's great book “Money, Interest and Prices” was certainly an important inspiration for my dissertation, mainly from a methodological point of view (in addition to Bent Hansen's and Paul Samuelson's work). This holds, in particular, 
for his insistence that macroeconomic aggregates should be derived from microeconomic foundations. Indeed, I went even further than him on this point, since I derived all behavior functions of individual households, as well as for individual firms, simultaneously in all markets - hence, in the case of households, not only labor supply and consumption were so derived but also the level of debt and the composition of the asset portfolio.

But my book was to some extent also a "revolt" against Patinkin. I wanted monetary and fiscal policy to influence the macroeconomy through many more different channels than usually assumed: via income effects, wealth effects, liquidity effects, and relative price effects - including intertemporal substitution, which was the reason why I systematically used two periods in the model: present and future. I also emphasized the role of credit rationing, which I saw as reflecting lenders' and borrowers' attitudes towards risk. I was inspired to take this broad approach by Robert Roosa's (non-formalized) ideas in the 1950s about what then was called "the new theory of credit control in the United States," which was also the title of a booklet that I published a few years before my $\mathrm{PhD}$ dissertation. Part of my dissertation would today be classified as "behavioral economics" in the sense that results from psychology research were integrated with more traditional formal economic analysis. In particular, I used Kurt Levin's theory of “the rising aspiration level” as a response to the individual's earlier success (or failure).

I have sometimes (perhaps not only jokingly) said that the work on a Swedish $\mathrm{PhD}$ thesis at that time was so demanding, and timed-consuming, that researchers in Sweden never recovered, and that as a result, the dissertation often represented the peak of their researcher career. In retrospect, I am sorry to say that my own dissertation may be yet another illustration, in the sense that this is the work of mine that I am least dissatisfied with.

Gylfason: Keynes never stood for Parliament: he did not think he had the right temperament for politics. Also, he was not a very good speaker. Yet Keynes probably had more influence on the political climate in Britain than most politicians in his day. The comparison is pertinent here, I think, because you have probably had more influence on the way Swedish politicians think about economic policy and organization than any other individual, and you have managed this without direct political involvement. So, if you want to wield influence as an economist, what, in your view, is the way to do it? 
Lindbeck: Although Keynes probably had considerable direct influence on policies by being an advisor to governments, there is no question that his main influence came about indirectly via his influence on our minds - largely via textbooks for several generations of students and newspaper articles by many economists and others who had been influenced by his ideas.

My own experience of policy advice and participation in public debate points in the same direction. To convince a politician in private about policy reforms is like writing in the sand on a beach. The writing will be washed out by the next storm. For instance, I convinced members of the (social-democratic) governments in the mid1960s and early 1970s of the advantage of removing rent control and to deregulate agriculture, but faced by gathering storms in public opinion, the authorities withdrew their proposals in both cases. By contrast, I think that I had some sustained influence on policy making in some cases when I turned directly to the general public. Examples are a great number of newspaper articles about the usefulness of markets, and articles where I criticized proposals to collectivize the ownership of shares in the late 1970s (via so called "wage-earner-funds"). Another example is the hotly discussed proposals by the so-called "Lindbeck-commission" in the early 1990s. In retrospect, I look positively at these general experiences: it is probably quite good that changes in policies reflect changes in public opinion rather than just private advice. After all, this is the idea of democracy.

Gylfason: Time was when Sweden was the richest of the five Nordic countries. Now Sweden is the poorest of the five, as measured by gross domestic product per inhabitant at international prices. What happened? Do you feel that Swedish economists have done enough to keep Sweden's economy in good health? Could they have done more? If so, how?

Lindbeck: There is no single reason for the relatively poor economic performance in Sweden from the mid-1960s or early 1970s. This is why the Lindbeck commission made no less than 113 different proposals to help the Swedish economy recover. If I would today, somewhat arbitrarily, single out some specific explanation, I would mention the attempts by the authorities during several decades to make life difficult for small firms, to discourage private capital accumulation, and to squeeze the profitability of firms - all examples of policies that accentuated the negative effects on private entrepreneurship of high taxes and a jungle of regulations. Swedish politicians tried, in fact, to have "capitalism without capitalists." I do not think that 
this ideal would be a vital, or even a viable, economic system in a long-term perspective. Several Swedish economists have certainly tried to make this point in the general discussion, but there are always others who challenge the view. A politician that listens quite selectively to the discussion among economists can always find some expert views that support his or her own priors.

Gylfason: You were not vocal in the Swedish debate on European Union membership before the referendum in 1995, but you came out in favor of Sweden's adoption of the euro before the referendum in 2002. Your side lost by a large margin. Now, both issues are clearly political as well as economic, but how do you respond to those who claim that Swedish economists have not done enough to guide public opinion?

Lindbeck: I think that Swedish economists did a pretty god job during the discussion leading up to the referendum on whether Sweden should join the EMU. The pros and cons where well spelled out in newspaper articles as well as in various reports, including the report by the so-called Calmfors commission. The EMU issue is, however, quite technical and also very complex. It is, therefore, natural that the voters formed their opinions very much on the basis of their own general attitudes towards the EU. For historical reasons (Sweden being outside the two World Wars), Swedes are less favorable to the entire EU project than citizens of other European countries, possibly except the UK. According to many empirical studies, Swedes do not feel much of a European identity. The referendum on EMU membership gave the electorate an opportunity to express their generally cool feelings towards the EU project as a whole.

Gylfason: The German economy seems to be in trouble: unemployment is still measured in double digits and growth remains sluggish. Professor Hans-Werner Sinn in Munich has recently published a book in German asking, even in the title of the book, whether Germany can still be saved. What lessons can Germany learn from Sweden?

Lindbeck: Germany's problems look somewhat similar to Sweden's problems ten years ago. One lesson from Sweden is that delaying reforms may result in an accumulation of serious problems. Another lesson is that an acute crisis may be used by politicians to make unpopular, but in a long-term view important reforms. Such crisis awareness certainly helped Sweden to push through a package of reforms in the first half of the 1990s. Maybe the crisis awareness in Germany has finally reached a 
point where such reforms are possible also in that country. Indeed, it seems that the German government is finally willing to use this opportunity.

The Swedish pension reform is worth looking at as an example of how welfarestate arrangements might be redesigned. The Swedish pension reform means that there are no longer any promises about the level of future benefits, not even as a ratio of earlier income. The level of the pension benefit is contingent on the growth of real wages and changes in life expectancy after retirement. This will make the pension system financially stable. The same general idea may be applied to other welfare-state benefits, by making the generosity of benefits contingent, for instance, on the future growth rate of the tax base and on the number of beneficiaries in each benefit system. Sweden also made a number of constitutional reforms in the 1990s, and I believe that the Germans should also take a new look at the appropriateness of their constitution, which was created during historically special circumstances.

Gylfason: How about labor market reform? Sweden has experienced a substantial decrease in unemployment in recent years without really implementing the labor market liberalization advocated by many economists, including you. How did this come about?

Lindbeck: During the depression in Sweden in the first half of the 1990s, open unemployment increased from about 3.5 to about 8.5 percent. Thanks to a cyclical upswing, starting in 1995, the current figure has been brought down to 5.5 percent. I had expected a stronger reduction during a stark cyclical upswing, in particular since Sweden has made a large number of structural reforms (although mainly outside the labor market) in the recent decade. We should also notice that about sixteen percent of people in working age today are financed by benefits other than unemployment benefits, such as labor market programs, sickness benefits, and early retirement. This means that figures on open unemployment give only a very partial picture of the situation in the labor market. I do not think that Swedish economists in general would say that the labor market functions well in the country - or in most other European countries for that matter.

Gylfason: Charles Kindleberger used to say: Economists, especially those from small countries, should not spend their lives away from home. Do you agree?

Lindbeck: I assume that Kindleberger meant that a scholar in social sciences can make more important contributions to the public discussion in the country where he, or she, grew up than in a country to which he or she has moved in mature age. Maybe 
this is also a reason why I have decided to stay in Sweden. Another reason could be that Sweden may be regarded as a kind of real-world economic-policy laboratory, although occasionally perhaps a "high-risk" one. There are some advantages to being close to such a laboratory. In particular, my choice of research topics has been strongly influenced by this proximity. This may be a reason why my choice of research topics, in particular in mature age, has been more influenced by real-world phenomena than by the academic research literature. There are, of course, also personal reasons for staying in Sweden, such as the privilege of working at the Institute for International Economic Studies (IIES), which by itself provides an international environment.

Gylfason: Indeed, you have probably been more intensively engaged in the economic-policy discussion in Sweden than any other economist over a period of some forty years - from stabilization and growth policies to housing and agriculture policy, welfare-state arrangements, and the issue of public versus private ownership of the means of production. And so on.

Lindbeck: That is probably true, and I could clearly not have played a similar role in a country to which I would have moved in mature age, in particular not in a large country.

Gylfason: Some natural scientists and others have expressed their doubts about the value of awarding Nobel prizes for economics. They claim that economics is too soft, too subjective, and too imprecise to merit such a prestigious prize. In a recent article in Dagens Nyheter, Sweden's leading daily newspaper, a professor in mathematical statistics and two others went as far as claiming that the economics prize reduces the value of all Nobel prizes. As a member of the Committee for Prize in Economic Science in Memory of Alfred Nobel for twenty-five years (1969-94) and its chairman for fourteen years (1980-94), how do you respond to these voices?

Lindbeck: It is true that Swedish newspapers, on some occasions, have published critical comments about the Economics Prize. Occasionally, members of the Royal Academy of Sciences have replied by arguing that there is a case for rewarding not only natural scientists but also social scientists. After all, one of the most striking developments in research after the time of Nobel's testament is the enormous expansion of social science research, not least in economics. There have, indeed, been suggestions to the effect that it would be better to have a prize in social sciences in general rather than just an economics prize. It is, however, easier to agree about a 
price in economics than in social sciences in general, which would have been a very heterogeneous area to reward. Moreover, the donor of the prize, Bank of Sweden, happened to be interested just in a prize in economics.

The specific criticism that you mentioned was based mainly on the assertion that mathematics is not very useful in economic analysis. This criticism is quite difficult to understand for active researchers in our field. There are, of course, examples of studies where mathematical formulations are unnecessary, such as when the conclusions follow directly from the assumptions, or when complex mathematics hides the lack of profound thinking. But a research field should not be judged by bad examples. We have all experienced, time after time, that many economic problems are too complex to be understood without the help of mathematical models. In particular, good mathematical models give predictions that we may not expect beforehand although we are often able to make a verbal, intuitive explanation afterwards. It is also clear that economists, in cooperation with statisticians, have developed methods for empirical, quantitative analysis that are rather sophisticated also in comparison with statistical methods used in natural sciences. Unfortunately, people outside our profession get most, or all, of their information about economics from the general policy discussion or from the business pages in newspapers.

Gylfason: How do you choose your research topics? What is your method?

Lindbeck: On the surface, it looks perhaps as if I have jumped from one field of economics to another during my career. But what I have done, without perhaps realizing it from the beginning, is that I have rather systematically focused my research on different aspects of economic policy. After my licentiate dissertation on fiscal policy, and my $\mathrm{PhD}$ dissertation on monetary theory and policy, I worked for a number of years on price regulations in housing and agriculture. Next, I turned to income distribution policies and employment policies. My latest field, where I still work, concerns different aspects of the welfare state, including social insurance and the provision of human services. I have also worked, from time to time, on the pure theory of economic policy, including attempts to endogenize government behavior as well as labor union behavior, and in this context to study different types of economic and political equilibria. My work on alternative economic systems may, of course, also be regarded as studies of economic policy; this system-oriented approach provided the structure to my booklet "The Political Economy of the New Left" in 1971. The booklet was largely inspired by my experiences on the Campuses of 
Columbia and Berkley in 1968-1969. Actually, it was Paul Samuelson who sent my manuscript to a commercial publisher, after I had given a talk on the issue at MIT. During the 1970s, in particular, I also worked on the consequences for economic policies in various fields of the internationalization of the economic system. Because of my specific experiences from Sweden, I have devoted quite a lot of time, maybe too much time, to the Swedish economy - reflected, for instance, in two books and also joint reports written with others.

Thus, while I have learnt analytical techniques from other economists, my inspiration about research topics mainly comes from real-world problems related to economic policy in various countries. This means that I have got my ideas about research topics mainly from news media and personal, every-day experiences. Obvious examples are the apparent importance of credit rationing, the permanent housing shortage in Sweden, the surplus production in European agriculture, traffic jams in cities, high persistence of unemployment in several European countries, strongly delayed incentive effects of higher tax rates and more generous welfare-state benefits, etc.

Gylfason: Traffic jams? Tell me more.

Lindbeck: After my writings about rent control and the housing shortage, it was natural to look at traffic jams as "street shortage" arising from the prevailing price system for street space. So, when the Government in early 1960 asked a number of economists to write essays (in Swedish) on resource allocation policies, I chose the topic "The price system in long-term planning." I argued that traffic jams were not a market failure but rather a "policy failure" because the streets are owned by local governments that set a zero price of using them, in spite of profound scarcity. This not only generates traffic jams; it also stimulates demands in the political process for knocking down buildings for the purpose of broadening the streets.

Gylfason: Did your work with Jörgen W. Weibull on formal models of probabilistic voting emanate from your previous writings on "endogenous politicians"?

Lindbeck: Yes, it did. After joint work with Jörgen on other issues, we found out that we had a common interest in how competition among political parties may influence redistribution policies. As in our previous joint work, we could exploit each other's comparative advantages as well as obvious complementarities. Indeed, I could not have written these papers all by myself - and Jörgen would perhaps not have done 
so either. We think that probabilistic voting models in many cases are more realistic descriptions of the outcome of political competition than median voter models.

Gylfason: After the collapse of communism, many leading economists, in America as well as in Europe, could not resist the urge to tackle the many challenging problems that arose from the transition from plan to market. You did not, however. Why not?

Lindbeck: I decided not to write about transition economies because the problems seemed too complex to me. I also thought that studies in this field would require too much institutional knowledge about the countries concerned. Moreover, I thought that experience in these countries would mainly reflect temporary phenomena, and that it would be difficult to draw general lessons from such studies.

I have today some difficulties with these rationalizations for not studying transition economies, since I have just started a paper on "Socio-Economic Interaction in China." The background for the paper is that I gave a number of lectures at various places in China in the spring of 2004 on "An Outsider's View of the Chinese Economy." Then, I made perhaps the usual non-economist's mistake: "now that I have put in several months of work on this issue (sunk costs!), I should put in whatever extra work is needed to produce a publishable paper!” So here I am working on a transition paper after all, although I try to limit the topic to issues where I can draw on my earlier work, in particular, my work on social and welfare-state issues, though in this case in the context of a different environment than in previous works.

Gylfason: You have, indeed, devoted extensive effort over the years to studying incentive problems in welfare states, problems that seem today to be as acute as ever, on both sides of the Atlantic and also farther afield. What is your take on economic research in this important field?

Lindbeck: This is my favorite research field today. But it is also a very difficult field. Many of us have strong priors on welfare issues, and it is often painful to find out that your priors do not always hold.

It is rather generally agreed among economists that increased welfare-state spending from a low initial level is likely not only to improve social conditions in a country but also to boost economic efficiency and growth. This assumes, of course, that the political system is willing, and able, to expand types of spending that actually improve income security and provide better quantity or quality (or both) of human capital, for instance via better sanitation, health care, and education. It is also 
generally agreed that if social spending increases year after year (as a share of GDP), it will sooner or later - long before it reaches 100 percent of GDP - reach a stage where the marginal benefits fall short of the marginal costs. This is, of course, the simple hypothesis of a hump-shaped relation between social spending and the level (or rate of growth) of GDP, with the former assumed to influence the latter.

Gylfason: Clearly, Haiti would benefit from increased social spending. Would Sweden?

Lindbeck: The problem of establishing, empirically, the peak of the hump is a formidable research task. First, you have problems of reverse causation and nonlinearities. Second, there are serious problems of aggregation. We have lots of partial evidence both about the return on investment in human capital and about efficiency losses due to tax wedges and moral hazard in the context of various benefit systems. But even when we have such information of partial effects, we confront the difficulty of adding up all partial effects.

It is, therefore, natural that many economists have taken shortcuts by simply regressing GDP growth on broad aggregates of tax revenues (as a share of GDP) and large aggregates of public-sector spending, such as transfer payments and public consumption. Overall, my reading of the literature in this field is that GDP growth does tend to be negatively associated with the size of taxes and government spending (as shares of GDP) when we confine the study to developed countries. But the simultaneity problem is certainly not solved in these studies. Moreover, we should never expect very robust relations between broad aggregates of this type, since the consequences for the level or growth rate of GDP must depend on the composition of public-sector spending, the detailed rules in various benefit systems, and the structure of taxes - among other things. Because of the difficulties in empirical research in this field, many writers have found it necessary to rely instead on scattered partial and even anecdotal evidence, although researchers necessarily feel somewhat uncomfortable about relying only on evidence of this type.

Gylfason: What do you think the Americans can learn from the Europeans about efficient and fair welfare policies?

Lindbeck: The European evidence indicates that it is possible, in principle, to bring about quite significant income security with the help of mandatory social insurance system, without a major collapse of national economies. The experience also shows that it is possible to provide fairly good education and health care also for 
low-income groups and their children. Moreover, several countries in Europe have come much farther than United States in launching voucher systems for human services (child care, education, and old-age care), in spite of the fact that the idea seems to have emerged in the United States, where it has been pushed by Rose and Milton Friedman. After all, vouchers are a brilliant way to combine collective financing with freedom of choice and competition among service providers.

It is, however, clear that most European countries today have serious problems with their welfare-state arrangements. Many of these systems are not financially stable. They have also resulted in undesired behavior adjustments, in particular, in the labor market. And some welfare-state arrangements have not been much adjusted to recent socioeconomic changes, such as slower productivity growth, unfavorable changes in demography, more unstable families, and globalization.

More generally, the European experience suggests that welfare-state spending easily "overshoots" reasonable limits, when many interest groups discover that they may have more to gain from generous government benefits than from additional work. By "overshooting" I mean that many observers, perhaps even a majority of the population, believe that the marginal costs considerably exceed the marginal benefits, but that the political process, including distributional conflicts in the political arena, make retreat difficult.

I have sometimes also asserted that there is a tendency for the welfare state to develop into a "transfer state." What I mean is that taxes may finally be so high that the government has to restrict spending on core government activities, such as collective goods (the legal system and research) to be able to finance galloping transfer payments. The government may also find it increasingly difficult to finance human services, such as education and health care, in particular, because the relative costs of such services tend to rise rapidly over time since productivity rises faster in the private sector than in the public-sector production of human services (Baumol's Law). We may sooner or later wind up in a situation when the government cannot satisfy citizens' demand for such services as long as they are tax-financed, even if households want to pay for more services of this type. In my judgment, several European countries approach this situation today. It is suggestive that aggregate spending on both education and health care today is higher in the United States than in Europe in spite of the fact - or perhaps just because of the fact - that such spending is to a much greater extent tax-financed in Europe than in the United States. 
The only way to solve this problem may be to shift to new types of financing income security and human services, such as users' fees and insurance premia. Individuals' willingness to pay for such services may then very well result in increased provision of such services.

Gylfason: What, then, could Europe learn from the United States in this field?

Lindbeck: The most negative lessons from welfare-state arrangements in the United States, in my view, is that there are high social costs of not taking effective actions to educate the lowest decile groups in the skill distribution. Moreover, in the health area, it is quite clear that ignorance about nutrition creates severe health hazards for the population. Preventive health care is poorly developed in the country, in particular among people in low-income groups. It is also obvious that the absence of mandatory health care insurance creates a very uneven protection across population groups against high costs in connection with health hazards.

There are, however, also positive lessons from welfare-state reforms in the United States. The experimentation with "work-in-benefits" for low-wage employees is important. In principle, it must be better to subsidize the work of individuals with low productivity than (as in several countries in Europe) to push up their wages to levels that make them unemployed, so that they have to be financed by various types of transfers. I think that Europe, sooner or later, will agree that the United States is on the right track in this specific field, in particular, if the system is extended to more groups in society. President Clinton's welfare reform was also important, because it showed that it is possible to increase employment among disadvantaged groups of citizens by making welfare benefits contingent on labor market training or work. I also believe that more flexibility in relative wages in Europe would boost labor mobility and stimulate investment in human capital. This is, however, not likely to occur to any large extent because of strong labor union power in most European countries.

Gylfason: Let us continue with the comparison between America and Europe. Labor market institutions differ in America and Europe - and, yes, also within Europe - and these differences have influenced the direction of labor market research on the two continents. How do you size up the situation? Is your distinction, in your work with Dennis Snower, between insiders and outsiders in labor markets less helpful in the United States than in Europe? 
Lindbeck: There are insider-outsider mechanisms at work also in the United States, since there are always costs of firing and hiring labor, although these costs certainly are lower in the United States than in most countries in Europe. And as long as there are such costs, which may take the form of insiders' harassment of underbidding outsiders, insiders are able to push up their wages above the reservation wage of outsiders without being fired. Perhaps we could argue that outsider status in the United States, much more than in Europe, is connected with poor education for, say, the two lowest deciles of individuals in the distribution of human capital. In Europe, outsider status has more to do with privileges for those who happen to have a job in the first place, in particular, if they have seniority status as a result of legislation that prescribes "last-in-first-out."

The main consequences of the insider-outsider divide in Europe is, I believe, that insiders can use business upswings to push up real wages without much concern for the negative effects on the employment prospects of unemployed workers and new entrants in the labor market. As a result, workers tend to be stuck in the unemployment pool (high unemployment persistence) for long periods of time after the emergence, and even after the reversal, of large unemployment-creating macroeconomic shocks.

Gylfason: Earlier in our conversation, you mentioned the strong, and increasing, political partisanship in academic circles in the United States, at a time when Sweden and Europe appear less politicized than before. Is it possible that this development has to do with differences in social organization in Europe and America - differences that have produced significantly greater inequalities in the distribution of incomes and wealth in the United States than in continental Europe? What do you think?

Lindbeck: It is certainly possible that this development has contributed to sharpening political conflicts in the country. But why would it have generated so much political controversy and partisanship just in academic circles? After all, academics have gained from this development. Are academics particularly altruistic on income distribution issues? I do not really know. Moreover, why hasn't the dramatic increase in unemployment in Europe, and the marginalization of many groups of citizens in that part of the world, resulted in increased political conflict, and increased partisanship among academics, in Europe? I am still confused on this issue. Or could it be the case that increased political polarization in the United States, also in the academic community, is a result of the country's more controversial foreign policy 
situation after the fall of the Soviet Union? It was easier to defend military activism in a world where the Soviet block was always a serious threat than to defend the United States' role today as "world police."

Gylfason: In the past few years, you have studied aspects of social norms - norms that can either help or hinder economic development, as your account of your travels with your father earlier in our conversation made clear. What is the story?

Lindbeck: While generous welfare-state arrangements were built up in Europe from the late 1940 to the late 1970 s, pronounced evidence of disincentive effects on work and benefit dependency did not emerge until the 1980s and 1990s. I have hypothesized that endogenous social norms may help explain this apparent paradox. More specifically, strong norms in favor of work, and against living off government benefits, emerged before the welfare state was built up, simply because it was difficult to survive without working during that period. Parents, schools, the Church, and other institutions also contributed to instilling and enforcing such norms. Then came the welfare state, which reduced the return on work as compared to non-work, and hence made it easier for the individual to survive without working. To begin with, the norms inherited from the past constrained and delayed the negative effects on work of the new incentive structure. Over time, however, some individuals started to use the generous benefit systems more and more, and institutions that had earlier preached the virtues of work stopped doing so. And when more individuals live on different types of benefits, the stigmatization of doing so is likely to recede. The delayed incentive effects then emerged.

I started my work in this field by rather informal (essayistic) papers, but have later formalized the ideas in a number of papers with Sten Nyberg and Jörgen W. Weibull. In these models, where individual market behavior is influenced by both economic incentives and norms, market behavior interacts with political behavior (voting). As we might expect, models with social norms easily give rise to multiple equilibria, one with low and one with high welfare-state spending.

Gylfason: Is there empirical evidence for this?

Lindbeck: Empirical research in this field is in its infancy. There are, however, some suggestive indications consistent with the hypothesis of endogenous social norms. One is the remarkable rise in the incidence of sickness absence in some countries (such as the Netherlands, Norway, and Sweden), which cannot be explained by deterioration in people's health. Another example is the huge increase in early 
retirement for asserted health reasons (for instance, in Belgium, Italy, and the Netherlands). It is also striking that the number of sick days varies drastically across neighborhoods in Sweden (differences as large as 30-40 days per year) even after controlling for about thirty explanatory variables concerning individual characteristics, type of municipality, type of profession, type of firm where people work, etc. It is also likely that unemployment persistence is accentuated by receding social norms in favor of work or against living on benefits from the government. What all this means is that endogenous changes in social norms may accentuate problems of moral hazard in connection with various welfare-state arrangements.

Gylfason: We mentioned before that you succeeded Gunnar Myrdal at the University of Stockholm in 1971, also as Director of the Institute for International Economic Studies, and you went on to run the Institute for a quarter of a century, until 1995. Under your direction, the Institute became an acknowledged world-class center of research. How did you do it?

Lindbeck: I concentrated on three tasks. First, I worked hard to attract funds to the institute by way of direct contact with the Treasury and the Department of Education, as well as by carefully drafted applications for research grants. Second, I was extremely selective in hiring and keeping researchers and graduate students. Third, I tried to stick to a small number of principles of running research institutes. A number of years ago, I summarized my experiences in the form of "Ten Commandments" for directors of research institutes. In tightly condensed form, they may be formulated as follows. (You find the full text on the homepage of the IIES.)

1. A research institute should try to reach the international research frontier and, indeed, contribute to push that frontier ahead.

2. For such ambitions to be fulfilled, it is important to publish internationally, and to abstain from having one's own printed publications.

3. It is also important to have outstanding foreign visitors at an institute - to import knowledge and to give a further boost to the international aspiration level.

4. Every researcher should develop his/her own international research network.

5. The activities should also be concentrated to a limited number of areas.

6. Successful research also requires that a critical mass of research effort is reached in one or a few areas.

7. A strong interaction between theoretical and methodological work, on the one hand, and applied research, on the other, is important for successful research. 
8. Employment decisions are the single most important administrative decisions at research institutes. The rest can be delegated, except fund raising.

9. It is a great advantage for a research institute to be part of a good university.

10. It is also useful if at least some members produce articles and books not only for the international research community, but also for laymen interested in economic issues. This is good both for the researchers themselves (who thereby develop their common sense) and for the possibilities for the institute to get research funds.

I want to believe that the Institute has been helped by adhering to principles like these.

Gylfason: Assar, you paint. You have exhibited your paintings in Stockholm on three occasions since 1997. William Baumol also paints and sculpts and Jan Tinbergen was a painter, to name but two, so you are not alone. Is there a connection between your painting and your work as an economist? Or do you inhabit two separate worlds that do not speak to one another?

Lindbeck: The main connection is a kind of complementarity. Research is a highly specialized activity. Many researchers, as well as other specialists, have a need to broaden their lives by also doing something quite different. In my case, this happens to be painting and music. Otherwise, I do not see much of a relation, or even similarity, between economic research and painting. Visual art operates via suggestion, while research operates via analysis. Some paintings, though not mine, may influence people's attitudes to various societal phenomena, for instance, by showing the horrors of war (such as in Goya) or misery due to poverty (such as in Kollwitz). But I have never seen any painting that has helped me understand how economic, political, or social systems function. To provide such understanding is the task of scientific research, although artistic activities other than visual art occasionally may help us understand how a society functions. Literature is, perhaps, the most obvious example - from the time of the ancient dramas to Dickens and Solzhenitsyn.

Gylfason: Yes, and Balzac. Thank you. 


\section{Published scientific works of Assar Lindbeck}

\section{Books}

\section{6}

The short-run effects of the government budget (Swedish), Treasury Department, SOU 1956:48, Stockholm.

\section{9}

The "new" theory of credit control in the United States, Stockholm Economic Studies, Almqvist \& Wiksell, Stockholm.

\section{3}

A study in monetary analysis, Stockholm Economic Studies, New Series III, Almqvist \& Wiksell, Stockholm.

The housing shortage. A study of the price system in the housing market (Swedish) (with Ragnar Bentzel and Ingemar Ståhl), Almqvist \& Wiksell, Stockholm.

1965

Agriculture and Economic Growth. A report by a group of experts for the OECD, OECD Publications No. 19, 365, Paris.

\section{7}

Monetary-fiscal analysis and general equilibrium, Yrjö Jahnsson Lectures, Helsinki.

\section{8}

Aims and means of agricultural policy (Swedish) (with Odd Gulbrandsen), Industriens Utredningsinstitut (IUI), Aldus, Stockholm.

Fiscal Policy for a Balanced Economy. Experiences, Problems and Prospects. A report by a group of experts for the OECD, OECD Publications No. 24, 827 , Paris.

1971

The political economy of the New Left, Harper \& Row, New York, also in Swedish.

Ekonomiska system (Economic systems), anthology ed. by Assar Lindbeck, Rabén \& Sjögren, Stockholm.

Samhällsekonomisk politik (Economic policy), collection of previously published papers (Swedish), Rabén \& Sjögren, Stockholm.

Rent control and the housing market (with Sören Blomquist) (Swedish), Almqvist \& Wiksell, Stockholm. 
1973

Blandekonomi i omvandling (Mixed economy in transition), four lectures on economic policy (Swedish), Aldus, Stockholm.

The national state in an internationalized world economy, lecture at Conjunto Universitario Candido Mendes, Rio de Janeiro.

The economics of the agricultural sector (with Odd Gulbrandsen), Industriens Utredningsinstitut, Stockholm, also in Swedish.

\section{5}

Swedish Economic Policy, Macmillan, London, also in Swedish.

1977

Flexible exchange rates and stabilization policy (conference volume edited with J. Herin and J. Myhrman), Macmillan, London.

1979

Fondfrågan (The issue of wage-earners' funds), essays (Swedish), Alba, Stockholm.

Inflation and employment in open economies (edited research volume from the Institute for International Economic Studies), North-Holland, Amsterdam.

1980

Ekonomi och mångfald (Economy and pluralism), two essays (Swedish), Akademilitteratur, Stockholm.

Inflation - global, international and national aspects, Gaston Eyskens Lectures, Leuven University Press, Leuven.

\section{1}

Makt och ekonomi (Power and economics), essays (Swedish), Akademilitteratur, Stockholm.

\section{6}

How much politics can the economy take? (Swedish), Bonnier-Fakta, Stockholm.

\section{7}

The Welfare State - Driving Forces, Functioning and Limits, Three Public Lectures, Lee Kuan Yew Distinguished Visitor Public Lecture Series.

1988

The Insider-Outsider Theory of Employment and Unemployment (with Dennis J. Snower), MIT Press, Cambridge, Massachusetts. 


\section{0}

Is the Welfare State in Crisis? and The Present Situation of Macroeconomics, Chung-Hua Series of Lectures by Invited Eminent Economists, No. 18, Taipei, Taiwan.

\section{2}

Can We Manage the Old Age Pensions in the Future? (Swedish), SNS Förlag, Stockholm.

\section{3}

Collected papers: Volume I "Macroeconomics and Economic Policy," Volume II "The Welfare State," Edward Elgar Publishing.

Nya villkor för ekonomi och politik, SOU 1993:16 (with P. Molander, T. Persson, O. Petersson, A. Sandmo, B. Swedenborg, and N. Thygesen).

Unemployment and Macroeconomics, MIT Press, Cambridge, Massachusetts.

\section{4}

Turning Sweden Around, (with P. Molander, T. Persson, O. Petersson, A. Sandmo, B. Swedenborg, and N. Thygesen), MIT Press, Cambridge, Massachusetts.

1997

The Swedish Experiment, SNS Förlag, also in Swedish.

\section{0}

Politisk makt med oklart ansvar, SNS Ekonomirådsrapport 2000 (with P. Molander, T. Persson, O. Petersson, and B. Swedenborg), SNS Förlag, Stockholm.

\section{Printed Research Papers}

1956

The effects of the government budget on consumption and investment 1954-56 (Swedish), Meddelanden från Konjunkturinstitutet, Series A:29, Stockholm.

1960

The theory of public finance (Swedish), Ekonomisk Tidskrift (Scandinavian Journal of Economics), No. 2.

\section{1}

The classical 'dichotomy' (Swedish), Ekonomisk Tidskrift (Scandinavian Journal of Economics), No. 1.

\section{3}

Monetary and exchange reserve policy in the case of European integration (Swedish), Nordiskt Nationalekonomiskt Jubileumsmöte, August. 


\section{4}

Location policy, Skandinaviska Banken Quarterly Review, No. 2.

\section{6}

Swedish agricultural policy in an international perspective, Skandinaviska Banken Quarterly Review, No. 4.

The method of isolation in economic statics - a pedagogical note, The Swedish Journal of Economics (Scandinavian Journal of Economics), No. 3.

1967

Rent control as an instrument of housing policy, in: A. Nevis (ed.) The economic problems of housing, International Economic Association, London.

\section{8}

Theories and problems in Swedish economic policy in the post-war period, American Economic Review, June, Supplement.

\section{9}

Labor market conditions, wages and inflation - Swedish experiences 1955-67 (with Lars Jacobson), Swedish Journal of Economics (Scandinavian Journal of Economics), No. 1.

\section{0}

Fiscal policy as a tool of economic stabilization, Kyklos, No. 1.

Paul Anthony Samuelson's contribution to economics, The Swedish Journal of Economics (Scandinavian Journal of Economics), No. 4. Also in: Contemporary Economists in Perspective, Greenwich/Conan., London, 1984.

Stabilization, allocation and distribution aspects of international reserves, Comments, in: International reserves - needs and availability, IMF, Washington.

1971

On the transmission mechanism of wage changes (with Lars Jacobson), Swedish Journal of Economics (Scandinavian Journal of Economics), No. 3

Problems of Stabilization Policy (Stabiliseringspolitiska problem) (Swedish), Nationalekonomiska Föreningens Förhandlingar, Stockholm, 4:1.

The efficiency of competition and planning, in: Michael Kaser and Richard Portes, eds., Planning and market relations, London.

The national state in an internationalized world economy (Swedish) (with Nils Lundgren), lecture for Nationalekonomiska Föreningens Förhandlingar. 
1972

Stabilization policy in an open high-employment economy - Swedish experiences, in: Emil Claassen and Pascal Salin, eds., Stabilization policies in interdependent economies, Amsterdam.

Symposium: Economics of The New Left, Rejoinder, The Quarterly Journal of Economics, No. 4, November.

Towards a new mercantilistic trade policy (Swedish), Statsøkonomisk Tidsskrift, $86(3 / 4)$.

1973

Research on Internal Adjustment to External Disturbances: A European View, in: C. Fred Bergsten, (ed.) The Future of the International Economic Order: An Agenda for Research, Lexington Books, Lexington, Mass.

Some fiscal and monetary policy experiments in Sweden, in: Credit allocation, techniques and monetary policy, Conference Series No. 11, Federal Reserve Bank of Boston.

1974

Is stabilization policy possible? - Time lags and conflicts of goals, in: Public finance and stabilization policy, Amsterdam.

Prize in economic science in honor of Alfred Nobel to Wassily Leontief for the input-output method, Scienza \& Tecnica 74, Milano.

Possible future international conflicts in a growing world economy, in: Economic science and problems of growth, Institut de la Vie, North-Holland, Amsterdam.

1975

Business cycles, politics and international economic dependence, Skandinaviska Enskilda Banken Quarterly Review, No. 2.

Economic systems and the economics of the New Left, lecture at Zurich University, in: Der Streit um die Gesellschaftsordnung, Schulthess Polygraphischer Verlag, Zurich.

Inequality and redistribution policy issues (Principles and Swedish Experience), in: Education, inequality and life chances, Vol. 2, OECD, Paris.

The changing role of the national state, Kyklos, Fasc. 1, also in Swedish.

1976

Approaches to exchange rate analysis - an introduction, Scandinavian Journal of Economics, No. 2; also in: J. Herin, A. Lindbeck, and J. Myhrman, eds., Flexible exchange rates and stabilization policy, Macmillan, London, 1977. 
Stabilization policy in open economies with endogenous politicians, Richard T. Ely Lecture, American Economic Review, Papers and Proceedings, No. 2, May.

\section{7}

International economic integration, in: B. Ohlin, P.-O. Hesselborn, and P.-M. Wijkman, eds., The international allocation of economic activity, Macmillan, London.

1978

Economic dependence and interdependence in the industrialized world, in: From Marshall plan to global interdependence, OECD, Paris.

1979

Imported and structural inflation and aggregate demand - The Scandinavian model reconstructed, in: A. Lindbeck, ed., Inflation and employment in open economies, North-Holland, Amsterdam.

\section{1}

Industrial policy as an issue in the economic environment, The World Economy, No. 4, December.

Work Disincentives in the Welfare State, Nationalökonomische Gesellschaft Lectures 79-80, Manz, Vienna.

\section{2}

Economics and Culture - the importance of a decentralized culture (Swedish), in: M. Johansson (ed.), Kulturen och Friheten, Timbro.

Emerging arteriosclerosis of the Western economies - Consequences for the Less Developed Countries, lecture at the International Center, New Delhi, India International Centre Quarterly, No 1.

Tax effects versus budget effects on labor supply, The Economic Inquiry, No. 4, October.

The political economy of cost inflation (with Thorvaldur Gylfason), Kyklos, Fasc. 3.

\section{3}

Budget expansion and cost inflation, American Economic Review, Papers and Proceedings, No. 2, May.

Interpreting income distributions in a Welfare State: The case of Sweden, European Economic Review, No. 2, April.

The recent slowdown on productivity growth, The Economic Journal, No. 1, March. 


\section{4}

Competing wage claims, cost inflation, and capacity utilization (with Thorvaldur Gylfason), European Economic Review, No. 1, February.

International and domestic preconditions for economic stability, Skandinaviska Enskilda Banken Quarterly Review, No. 2.

The international economic environment and industrialization possibilities in developing countries, Industry and Development, No. 12, UNIDO, Vienna.

Union rivalry and wages: An oligopolistic approach (with Thorvaldur Gylfason), Economica, No. 2, May.

\section{5}

Cooperation, Harassment, and Involuntary Unemployment (with Dennis J. Snower), American Economic Review, No. 1, March 1988.

Explanations of unemployment (with Dennis J. Snower), Oxford Review of Economic Policy, No. 2.

Redistribution policy and the expansion of the public sector, Journal of Public Economics, No. 4, Dec.

The prize in economic science in memory of Alfred Nobel, Journal of Economic Literature, No. 1, March.

What is wrong with the West European economies?, The World Economy, No. 2, June.

\section{6}

Endogenous unions and governments: A game-theoretic approach (with Thorvaldur Gylfason), European Economic Review, No. 1, February.

Intergenerational aspects of public transfers, borrowing and debt (with Jörgen W. Weibull), Scandinavian Journal of Economics, No 1.

Involuntary unemployment as an insider-outsider dilemma (with Dennis J. Snower), in: W. Beckerman, ed., Wage rigidity, employment, and economic policy, Duckworth, London.

Wage setting, unemployment, and insider-outsider relations (with Dennis J. Snower), American Economic Review, Papers and Proceedings, No. 2, May.

1987

Balanced-budget redistribution as political equilibrium (with Jörgen W. Weibull), Public Choice, No. 52.

Efficiency wages versus insiders and outsiders (with Dennis J. Snower), European Economic Review, February/March, Papers and Proceedings, No. $1 / 2$. 
Is the Welfare State in Trouble? Eastern Economic Journal, No. 4, October/December.

Strike and Lock-Out Threats and Fiscal Policy (with Dennis J. Snower), Oxford Economic Papers, No. 4, December.

Union activity and wage-employment movements (with Dennis J. Snower), European Economic Review, Papers and Proceedings, February/March, No. 1/2.

\section{8}

Altruism and Time-Consistency - The Economics of Fait Accompli (with Jörgen W. Weibull), Journal of Political Economy, No. 6, December.

Consequences of the Advanced Welfare State, The World Economy, No. 11, March.

Individual Freedom and Welfare State Policy, Schumpeter Lecture, European Economic Association Annual Congress, Copenhagen 1987, European Economic Review, Papers and Proceedings, March, No. 2/3.

Job Security, Work Incentives and Unemployment (with Dennis J. Snower), Scandinavian Journal of Economics, No. 4.

Long-Term Unemployment and Macroeconomic Policy (with Dennis J. Snower), American Economic Review, Papers and Proceedings, No. 2, May.

Welfare effects of alternative forms of public spending (with Jörgen W. Weibull), European Economic Review, No. 1, January.

\section{9}

Macroeconomic Policy and Insider Power (with Dennis J. Snower), American Economic Review, Papers and Proceedings, No. 2, May.

Policy Autonomy Vs. Policy Coordination in the World Economy, in: Hans Tson Söderström (ed.), One Global Market, SNS.

Remaining Puzzles and Neglected Issues in Macroeconomics, Scandinavian Journal of Economics, No. 2.

Symmetric and Asymmetric Persistence of Labor Market Shocks (with D. Begg, Ch. Martin, and D. Snower), The Japanese and International Economies, No. 4, December.

1990

Cooperation, Harassment and Involuntary Unemployment: Reply (with Dennis J. Snower), American Economic Review, No. 3, June. 
Demand- and Supply-side Policies and Unemployment: Policy Implications of the Insider-Outsider Approach (with Dennis J. Snower), Scandinavian Journal of Economics, No. 2.

Inter-Industry Wage Structure and the Power of Incumbent Workers (with Dennis J. Snower), in: Labor Relations and Economic performance, R. Brunetta and C. dell'Aringa (eds.), Macmillan Press.

Public Spending and private Services - Macroeconomic Effects (with Parameswar Nandakumar) Oxford Economic Papers, No. 3, July.

Wages, Money, and Exchange Rates With Endogenous Unions and Governments (with Thorvaldur Gylfason), Journal of Policy Modelling, No. 3, Autumn.

\section{1}

Interactions between the Efficiency Wage and Insider-Outsider Theories (with Dennis J. Snower), Economics Letters, No. 2, October.

Microfoundations of Unemployment Theory, Labour, No. 3, Winter.

Public Finance for Market-Oriented Developing Countries, in: Kim and Krausse (eds.) Economic Development and Trade Liberalization.

Unemployment and Labor Market Imperfections, in: Issues in contemporary Economics, Vol. 2, Macroeconomics and Macroeconometrics, Mark Nerlowe (ed.), Macmillan Press.

\section{2}

Macroeconomic Theory and the Labor Market, Presidential Address at the EEA Congress in Cambridge, European Economic Review, Papers and Proceedings, No. 2/3, April.

1993

A Model of Political Equilibrium in Representative Democracy (with Jörgen W. Weibull), Journal of Public Economics, No. 2, June.

Options for Economic and Political Reform in Sweden (with Molander, P., Persson, T., Petersson, O., Sandmo, A., Swedenborg, B., and Thygesen, N.) Economic Policy 17, October.

\section{4}

Overshooting, Reform and Retreat of the Welfare State, De Economist, 142(1).

The Interactions of Monetary Policy and Wages (with Thorvaldur Gylfason), Public Choice, No. 2, April.

The Welfare State and the Employment problem, American Economic Review, Papers and Proceedings, No. 2, May. 
Uncertainty under the Welfare State - Policy-Induced Risk, The Geneva Papers on Risk and Insurance, No. 73.

1995

Hazardous Welfare-State Dynamics, American Economic Review, Papers and Proceedings, No. 2, May.

How are product demand changes transmitted to the labour market? (with Dennis J. Snower) The Economic Journal, No. 423, March.

Welfare-State Disincentives with Endogenous Habits and Norms, Scandinavian Journal of Economics, No. 4.

1996

Reorganization of Firms and Labor Market Inequality (with Dennis J. Snower), American Economic Review, Papers and Proceedings, No. 2, May.

The West European Employment Problem, Weltwirtschaftliches Archiv, 132(4).

Full Employment and the Welfare State, The American Economist, 42(1), Spring.

1997

Incentives and social norms in household behavior, American Economic Review Papers and Proceedings, No. 2, May.

Optimal Actuarial Fairness in Pension Systems - A Note (with John Hassler), Economics Letters, 55(2).

The Swedish Experiment, Journal of Economic Literature, No. 3, September.

Welfare State Dynamics, in: The Welfare State in Europe, Challenges and Reforms, European Economy (European Commission, Directorate-General for Economic and Financial Affairs), No. 4.

\section{8}

How Can Economic Policy Strike a Balance between Economic Efficiency and Income Equality? In: Income Inequality: Issues and Policy Options, The Federal Reserve Bank of Kansas City.

Incentives in the Welfare State: Lessons for Would-Be Welfare States, The Austin Robinson Lecture, Tunis, December 1995. In: Y. Mundlak (ed.), Contemporary Economic Issues, Proceedings of the Eleventh World Congress of the International Economic Association, Vol. 2: Labour, Food and Poverty, Macmillan Press, London.

New Keynesianism and Aggregate Economic Activity, Economic Journal, No. 446, January. 
Price Dynamics and Production Lags (with Dennis J. Snower), American Economic Review, Papers and Proceedings, No. 2, May.

Social Norms and Economic Incentives in the Welfare State (with Sten Nyberg and Jörgen W. Weibull), Quarterly Journal of Economics, No. 1, February.

\section{0}

The Labor Market, in: Governance, Equity and Global Markets, Proceedings of the Annual Bank Conference on Development Economics in Europe, Paris, June.

Multitask Learning and the Reorganization of Work: From Tayloristic to Holistic Organization (with Dennis J. Snower), Journal of Labor Economics, No. 3, July.

Swedish Economic Growth in an International Perspective, Swedish Economic Policy Review, No. 1.

The ICT Revolution in Consumer Product Markets (with Solveig Wikström), Consumption, Markets and Culture, No. 1.

2001

Centralized Bargaining and Reorganized Work: Are They Compatible? (with Dennis J. Snower), European Economic Review, No. 10, December.

Insiders versus Outsiders (with Dennis J. Snower), Journal of Economic Perspectives, No. 1, Winter.

Lessons from Sweden for Post-Socialist Countries, in: J. Kornai, S. Haggard, and R. Kaufman, eds., Reforming the State. Fiscal and Welfare Reform in Post-Socialist Countries, Cambridge University Press.

The Sveriges Riksbank (Bank of Sweden) Prize in Economic Sciences in Memory of Alfred Nobel 1969-2000, The Nobel Foundation's Internetmuseum (www.nobel.se/economics/articles/lindbeck).

\section{2}

Pensions and Contemporary Socioeconomic Change, in: M. Feldstein and H. Siebert (eds.) Social Security Pension Reform in Europe, NBER Conference Report, University of Chicago Press, Chicago.

The European Social Model: Lessons for Developing Countries, Asian Development Review, No. 1.

Unemployment - Structural, in: N. J. Smelser and P. B. Baltes (eds.) International Encyclopedia of the Social and Behavioral Sciences, Pergamon, Elsevier Science, Oxford. 
Changing Tides for the Welfare State: An Essay, in: S. Cnossen and H.-W. Sinn (eds.), Public Finance and Public Policy in the New Century, CESifo Seminar Series, MIT Press, Cambridge, MA.

E-exchange and the Boundary between Households and Organizations (with Solveig Wikström), Kyklos, No. 2, June.

Social Model: Lessons for Developing Countries, in: R. Pethig and M. Rauscher (eds.) Challenges to the World Economy, Festschrift for Horst Siebert, SpringerVerlag, Berlin-Heidelberg.

Social Norms and Welfare State Dynamics (with Sten Nyberg and Jörgen W. Weibull), Journal of the European Economic Association, No. 1.

The Gains from Pension Reform (with Mats Persson), Journal of Economic Literature, No. 1, March.

\section{4}

An Essay on Welfare State Dynamics, in B. Södersten (ed.) Globalization and the Welfare State, Palgrave Macmillan, Basingstoke and New York.

Improving the Performance of the European Social Model - The Welfare State over the Life Cycle, in J. Gaul (ed.) Building a Dynamic Europe, Cambridge University Press.

The Sveriges Riksbank (Bank of Sweden) Prize in Economic Sciences in Memory of Alfred Nobel 1969-2004, The Nobel Foundation's Internetmuseum (www.nobel.se/economics/articles/lindbeck). 


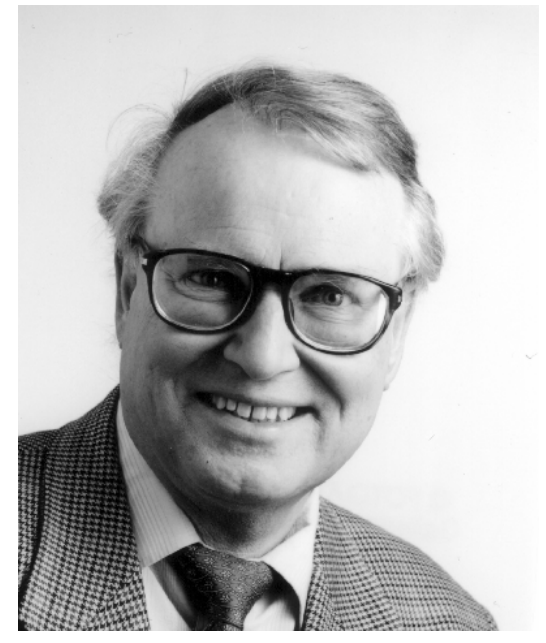

Figure 1. Assar Lindbeck

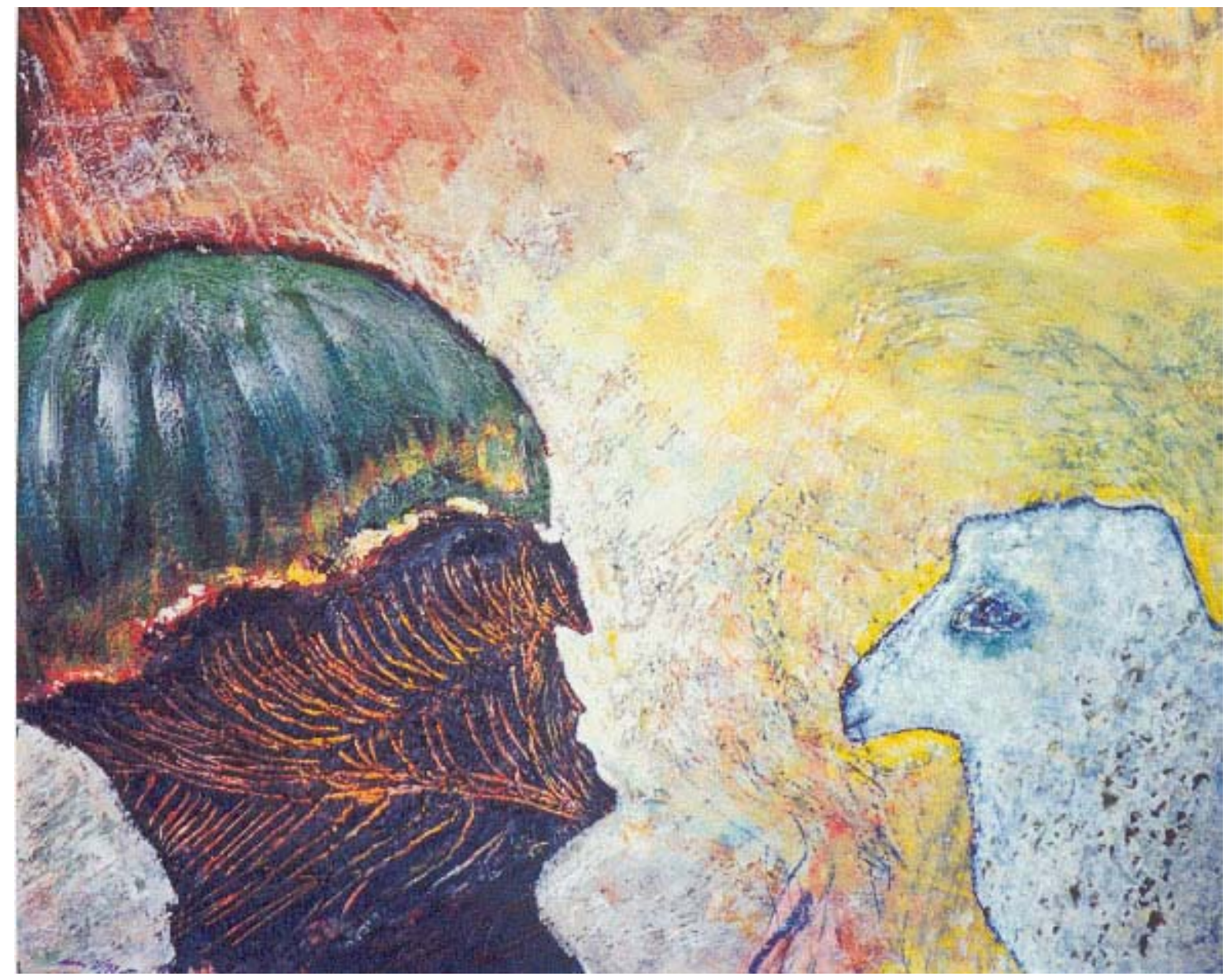

Figure 2. Confrontation by Assar Lindbeck 


\title{
CESifo Working Paper Series
}

\author{
(for full list see www.cesifo.de)
}

1346 Wolfgang Eggert and Martin Kolmar, Contests with Size Effects, December 2004

1347 Stefan Napel and Mika Widgrén, The Inter-Institutional Distribution of Power in EU Codecision, December 2004

1348 Yin-Wong Cheung and Ulf G. Erlandsson, Exchange Rates and Markov Switching Dynamics, December 2004

1349 Hartmut Egger and Peter Egger, Outsourcing and Trade in a Spatial World, December 2004

1350 Paul Belleflamme and Pierre M. Picard, Piracy and Competition, December 2004

1351 Jon Strand, Public-Good Valuation and Intrafamily Allocation, December 2004

1352 Michael Berlemann, Marcus Dittrich and Gunther Markwardt, The Value of NonBinding Announcements in Public Goods Experiments: Some Theory and Experimental Evidence, December 2004

1353 Camille Cornand and Frank Heinemann, Optimal Degree of Public Information Dissemination, December 2004

1354 Matteo Governatori and Sylvester Eijffinger, Fiscal and Monetary Interaction: The Role of Asymmetries of the Stability and Growth Pact in EMU, December 2004

1355 Fred Ramb and Alfons J. Weichenrieder, Taxes and the Financial Structure of German Inward FDI, December 2004

1356 José Luis Moraga-González and Jean-Marie Viaene, Dumping in Developing and Transition Economies, December 2004

1357 Peter Friedrich, Anita Kaltschütz and Chang Woon Nam, Significance and Determination of Fees for Municipal Finance, December 2004

1358 M. Hashem Pesaran and Paolo Zaffaroni, Model Averaging and Value-at-Risk Based Evaluation of Large Multi Asset Volatility Models for Risk Management, December 2004

1359 Fwu-Ranq Chang, Optimal Growth and Impatience: A Phase Diagram Analysis, December 2004

1360 Elise S. Brezis and François Crouzet, The Role of Higher Education Institutions: Recruitment of Elites and Economic Growth, December 2004 
1361 B. Gabriela Mundaca and Jon Strand, A Risk Allocation Approach to Optimal Exchange Rate Policy, December 2004

1362 Christa Hainz, Quality of Institutions, Credit Markets and Bankruptcy, December 2004

1363 Jerome L. Stein, Optimal Debt and Equilibrium Exchange Rates in a Stochastic Environment: an Overview, December 2004

1364 Frank Heinemann, Rosemarie Nagel and Peter Ockenfels, Measuring Strategic Uncertainty in Coordination Games, December 2004

1365 José Luis Moraga-González and Jean-Marie Viaene, Anti-Dumping, Intra-Industry Trade and Quality Reversals, December 2004

1366 Harry Grubert, Tax Credits, Source Rules, Trade and Electronic Commerce: Behavioral Margins and the Design of International Tax Systems, December 2004

1367 Hans-Werner Sinn, EU Enlargement, Migration and the New Constitution, December 2004

1368 Josef Falkinger, Noncooperative Support of Public Norm Enforcement in Large Societies, December 2004

1369 Panu Poutvaara, Public Education in an Integrated Europe: Studying to Migrate and Teaching to Stay?, December 2004

1370 András Simonovits, Designing Benefit Rules for Flexible Retirement with or without Redistribution, December 2004

1371 Antonis Adam, Macroeconomic Effects of Social Security Privatization in a Small Unionized Economy, December 2004

1372 Andrew Hughes Hallett, Post-Thatcher Fiscal Strategies in the U.K.: An Interpretation, December 2004

1373 Hendrik Hakenes and Martin Peitz, Umbrella Branding and the Provision of Quality, December 2004

1374 Sascha O. Becker, Karolina Ekholm, Robert Jäckle and Marc-Andreas Mündler, Location Choice and Employment Decisions: A Comparison of German and Swedish Multinationals, January 2005

1375 Christian Gollier, The Consumption-Based Determinants of the Term Structure of Discount Rates, January 2005

1376 Giovanni Di Bartolomeo, Jacob Engwerda, Joseph Plasmans, Bas van Aarle and Tomasz Michalak, Macroeconomic Stabilization Policies in the EMU: Spillovers, Asymmetries, and Institutions, January 2005 
1377 Luis H. R. Alvarez and Erkki Koskela, Progressive Taxation and Irreversible Investment under Uncertainty, January 2005

1378 Theodore C. Bergstrom and John L. Hartman, Demographics and the Political Sustainability of Pay-as-you-go Social Security, January 2005

1379 Bruno S. Frey and Margit Osterloh, Yes, Managers Should Be Paid Like Bureaucrats, January 2005

1380 Oliver Hülsewig, Eric Mayer and Timo Wollmershäuser, Bank Loan Supply and Monetary Policy Transmission in Germany: An Assessment Based on Matching Impulse Responses, January 2005

1381 Alessandro Balestrino and Umberto Galmarini, On the Redistributive Properties of Presumptive Taxation, January 2005

1382 Christian Gollier, Optimal Illusions and Decisions under Risk, January 2005

1383 Daniel Mejía and Marc St-Pierre, Unequal Opportunities and Human Capital Formation, January 2005

1384 Luis H. R. Alvarez and Erkki Koskela, Optimal Harvesting under Resource Stock and Price Uncertainty, January 2005

1385 Ruslan Lukach, Peter M. Kort and Joseph Plasmans, Optimal R\&D Investment Strategies with Quantity Competition under the Threat of Superior Entry, January 2005

1386 Alfred Greiner, Uwe Koeller and Willi Semmler, Testing Sustainability of German Fiscal Policy. Evidence for the Period 1960 - 2003, January 2005

1387 Gebhard Kirchgässner and Tobias Schulz, Expected Closeness or Mobilisation: Why Do Voters Go to the Polls? Empirical Results for Switzerland, 1981 - 1999, January 2005

1388 Emanuele Bacchiocchi and Alessandro Missale, Managing Debt Stability, January 2005

1389 Assar Lindbeck and Dirk Niepelt, Improving the SGP: Taxes and Delegation rather than Fines, January 2005

1390 James J. Heckman and Dimitriy V. Masterov, Skill Policies for Scotland, January 2005

1391 Emma Galli \& Fabio Padovano, Sustainability and Determinants of Italian Public Deficits before and after Maastricht, January 2005

1392 Angel de la Fuente and Juan Francisco Jimeno, The Private and Fiscal Returns to Schooling and the Effect of Public Policies on Private Incentives to Invest in Education: A General Framework and Some Results for the EU, January 2005

1393 Juan C. Conesa and Carlos Garriga, Optimal Response to a Demographic Shock, January 2005 
1394 Christian Gollier, Optimal Portfolio Management for Individual Pension Plans, February 2005

1395 Ruslan Lukach, Joseph Plasmans and Peter M. Kort, Innovation Strategies in a Competitive Dynamic Setting, February 2005

1396 Gebhard Kirchgässner, (Why) Are Economists Different?, February 2005

1397 Marko Köthenbürger, Panu Poutvaara and Paola Profeta, Why are More Redistributive Social Security Systems Smaller? A Median Voter Approach, February 2005

1398 Gabrielle Demange, Free Choice of Unfunded Systems: A First Assessment, February 2005

1399 Carlos Fonseca Marinheiro, Sustainability of Portuguese Fiscal Policy in Historical Perspective, February 2005

1400 Roel M. W. J. Beetsma and Koen Vermeylen, The Effect of Monetary Unification on Public Debt and its Real Return, February 2005

1401 Frank Asche, Petter Osmundsen and Maria Sandsmark, Is It All Oil?, February 2005

1402 Giacomo Corneo, Media Capture in a Democracy: The Role of Wealth Concentration, February 2005

1403 A. Lans Bovenberg and Thijs Knaap, Ageing, Funded Pensions and the Dutch Economy, February 2005

1404 Thiess Büttner, The Incentive Effect of Fiscal Equalization Transfers on Tax Policy, February 2005

1405 Luisa Fuster, Ayşe İmrohoroğlu and Selahattin İmrohoroğlu, Personal Security Accounts and Mandatory Annuitization in a Dynastic Framework, February 2005

1406 Peter Claeys, Policy Mix and Debt Sustainability: Evidence from Fiscal Policy Rules, February 2005

1407 James M. Malcomson, Supplier Discretion over Provision: Theory and an Application to Medical Care, February 2005

1408 Thorvaldur Gylfason, Interview with Assar Lindbeck, February 2005 